\title{
DUTIES, OUGHTS AND JESSE PRINZ'S AGENT-RELATIVISM
}

\author{
DEVERES ESTRITOS, DEVERES PRÁTICOS E O RELATIVISMO BASEADO \\ NO AGENTE DE JESSE PRINZ
}

MARCO ANTONIO DE OLIVEIRA AZEVEDO ${ }^{1}$

(UNISINOS, Brasil)

\begin{abstract}
In The Emotional Construction of Morals (2007), Jesse Prinz offers a coherent naturalist approach on the foundations of human moral normativity. He classifies his view as a sensibility theory, a realist approach conspicuously opposed to the anti-realist bent of traditional emotivism. I sympathize with Prinz's general approach; nevertheless, I have some specific disagreements. The first concerns the "is-ought" problem. I don't think it is possible to build a realist, and a naturalist, approach in ethics without answering the famous problem with a positive stance. That is, without showing that it is actually possible to make the suspect transition-at least if we take "normativity" as a natural fact (as Hume, I think, actually thought). Here I will evaluate what I think are the main issues of Prinz's approach. One issue that deserves to be commented on is the contrast between Prinz's view and John Searle's well-known approach regarding the is-ought problem. Prinz thinks that Searle's argument favouring the passage from an "is" to an "ought" is not cogent, but the correct understanding of Searle's argument requires assuming "obligations" (and duties) as factual. Therefore, what a naturalist theory must explain is how it is possible to pass from the fact that one is under a particular obligation to the supposed required action (or, in more fashionable words, how duties can be "agent-relative reasons for action"). In effect, I will present my approach on the concept of "reason for action," influenced by Judith Jarvis Thomson's approach, and her distinction between "duties" and "oughts." In the final section I will make some comments on the problem of relativism. I agree with Prinz that descriptive relativism is true; but Prinz is committed to a form of agent-relativism. I will present arguments against agent-relativism that depend on the acceptance of a clear distinction between "duty" and "ought."
\end{abstract}

Key Words: Prinz. Emotionalism. Hume. Relativism. Moral Naturalism. Is-Ought.

\section{Introduction}

I want to discuss some of Jesse Prinz's ideas in defence of the new empiricist approach to morality, presented in The Emotional Construction of Morals (2007)-hereafter ECM. I will do this by means of contrast between his claims, and my opinions about what represents the best approach on the same issues. So, let me begin by comparing his project, and the project I am to argue for. This is Prinz's empiricist project:

1. Morality derives from us.

ethic@-Florianópolis v.12, n.2, p.143-168, Dez. 2013. 
2. The good is what we regard as good and the obligatory is what we regard as obligatory.

3. The "we" refers to the person making a moral claim AND the cultural group with which that individual affiliates.

4. A moral belief is the mental act of regarding something as good or obligatory.

5. What we (or someone) actually believe is an empirical matter; hence, to figure it out is a descriptive task.

6. Normative ethics can be approached as a social science.

Here is my version:

1. Morality derives from "us."

2. The good is what "we" regard as good and the obligatory is what "we" regard as obligatory.

3. But the "we" does not refer to the person making a moral claim. The "we" refers to a large group of persons that follow a common social practice, a common human social practice.

4. A moral belief is the mental act of regarding something as good, or obligatory. Nonetheless, assuming that it is not possible to obey a rule "privately" (for, otherwise, thinking one was obeying a rule would be the same thing as obeying it), it follows that to regard something as good or obligatory cannot be the same as being good or obligatory - since to think one is obeying a rule is not to obey a rule (as Wittgenstein famously remarked).

5. What someone actually believes is an empirical matter; hence, figuring it out is a descriptive task.

6. Rule behaviour is also an empirical matter; hence, to figure it out is also a descriptive task.

7. Empirical facts, including ruled common behaviour and mental acts, events and states (like thinking, feeling, beliefs and desires), exhaust all there is objectively in the world about morality. Normative ethics can be approached as a social science. 
Now, let us see how these two different yet similar approaches-perhaps in several parts indeed complimentary_can be compared.

\section{On Jesse Prinz's emotionalism}

Let me begin by presenting a view I think is plausible - besides non-normative facts (physical, chemical, biological and neurological facts), there are "normative facts" that explain human normative behaviour. Morals facts are a sub-group of normative facts. Morality concerns obligation; that is, the impermissibility of not doing some things (Timmons 2013, 7-9). If I do not have the permission to do something, I am therefore obligated to refrain from doing it. That I am obligated can be considered a matter of social fact; nevertheless, an acceptable alternative view is that it not only can be a social matter, but it necessarily must be a social matter. Some people think that it can be also a matter of an independent "moral" fact. Others think that true obligations are necessarily a matter of an independent moral fact. But it is very plausible that all those "moral facts" are also social facts. Therefore, if those moral facts are normative moral facts we can infer moral conclusions from them.

Non-moral conclusions can obviously be inferred from non-moral facts. From the fact "the ice is thin" someone can infer that ice-skating at the lake is not advisable, but the conclusion is not a moral one. Nonetheless, there is a sense that the proposed fact that "the ice is thin" is a "normative fact," in the sense that it is a fact (or a kind of fact) that pertains to people's decisions, in this case especially to ice-skaters.

Of course, a follower of Hume's Law_an alleged law that I prefer to call "Hare's Law," since it was stated by the philosopher Richard Hare (1963, 108), and its common version is usually influenced by Hare's views on the matter, not Hume's ${ }^{2}$ — will say that my example is not a good example, for it expresses an enthymeme. Nonetheless, this objection only applies for a formalist — one that thinks that practical reasoning needs to express deductive arguments, that is, entailments. I'm not a formalist. Practical reasoning is not a formal argument that must obey the inflexible rules of inference or deduction. Patricia Churchland offered this notion-practical reasoning is best explained as inferences to the best decision (Churchland 2009). Practical reasoning is case-based. They necessarily do not invoke normative explicit premises in the form 
of general or universal principles, universal rules, etc. Practical reasoning is solutions to practical problems. Some of them are good, others bad; but some are better than others, and some are less good, and by this reason are revisable. It follows the same rationales that guide inferences to the best explanations (IBE), a form of reasoning that Charles Sanders Peirce called "abductive," and are the landmark of non-deductive "theoretical" reasoning. IBE are also case-based reasoning. In IBE, conclusions are the best explanations we have, represented by things, or relevant facts we know, or are acquainted to; they likely increase the posterior probability of those facts. Making an analogy, practical decisions are good (or right) if they enhance the propriety of those normative facts that calls for an appropriate behaviour. They improve the likelihood that those facts (the normative facts) are normative given the circumstances.

Practical conclusions, hence, are not expressed by assertoric sentences, or by propositions, or by any semantic structures that can logically follow from other sentences or propositions of a same semantic kind. Actually, neither conclusions of reasoning understood as beliefs are the kind of thing that follows logically from other beliefs understood as premises. Reasoning is not an argument; reasoning is mental action, and arguments are not actions of any kind. Arguments are abstract structures whose components are sentences or perhaps propositions (it depends if we are nominalists, or realists, about the nature or the reality of arguments). Reasoning is quite different; they are mental acts whose purpose is to revise or change beliefs. In the case of practical reasoning, their purpose is to change the world by means of action. "Syllogism is a form of argument and although there is practical reasoning, there is not obviously any such thing as practical argument or logic and so not obviously any such thing as a practical syllogism" (Harman 1976; 1986, 6). Here I am following Gilbert Harman's views on the subject and I am convinced that he is right (Harman's view is that Logic is the science whose general scope is to study "what follows from what." It is a theory of implication, but not a theory of reasoning. In some sense, Logic is a mathematical discipline. It is not a theory about how we can reason well or correctly - a general methodological problem).

Following this belief, the so-called "premises" of practical reasoning are best understood as reasons for action. Hence, the correct question should be whether facts could be offered as reasons for doing or not doing something. It is plainly intuitive, or rather it is obvious, that the fact that the ice is thin can be offered (to or by someone) as a "sufficient" reason for not skating on a lake (that is, that the ice is thin is a strong prima facie or pro tanto reason for not skating on 
the lake - of course, here we are using the word "sufficient" not in a logical sense but in its very ordinary usage).

Unfortunately, we cannot linger on the complex issue of the "logic" of practical reasoning. Thus, I will put this issue aside and move on to ponder one of Prinz's core ideas - the idea that "ought" expresses a "prescriptive sentiment."

\section{Ought and prescriptions}

Prinz says that "ought" expresses a "prescriptive sentiment" and that this is a complex emotional disposition. The idea is that if one has this sentiment then they are disposed to engage in this conduct, and also disposed to feel badly if they don't. Prinz's example is Smith's judgment that one ought to give to charity. This judgment expresses Smith's prescriptive sentiment that disposes him to feel badly if he doesn't give to charity, and angry if you don't give to charity.

But the judgment that one ought to give to charity is a "weasel" judgment—it can mean a lot of things, or nothing (in this case, it would be like an egg without its yolk). It can at least meaningfully express two different situations: it can mean Smith's mental act of simply thinking about a "moral rule" that people ought to give to charity, but it can also express Smith's decision about what he should do in a concrete situation. Suppose that by means of a call centre a philanthropic entity asks Smith for charity, and that in the course of the conversation Smith thinks about whether he ought to give to charity. In a different situation, Smith is in a Philosophy class and he is thinking about whether people ought to give to charity. Prinz's view implies that if Smith concludes favourably in both cases his conclusion expresses a sentiment that disposes him to feel badly if eventually he does not give the said money to charity. Prinz understands that this expressive character of "ought" is what characterizes the emotive meaning of this word.

It is plausible that Smith's honest practical conclusion is in some way attached to sentiments that dispose him to feel badly if he eventually does not fulfill the deed, but why say that it "expresses" this sentiment? Why not rather say that the practical conclusion expresses a "deliberation?" In this case, the word "ought" simply signalizes the deliberation. ${ }^{3}$ Besides that, different kinds of feelings can be attached to the act, and different dispositional feelings can be evoked in the case of frustration. For example, in the case of charity-one of the most preferred cases in philosophical literature - the sentiment aroused in the case of non-fulfillment can be

ethic@ - Florianópolis v.12,n.2, p.143 - 168, Dez. 2013. 
regret or guilt. But if the deliberation did not express a moral content, the sentiment aroused would be substantially different. Suppose that Smith is thinking about what to do and concludes that he ought to accept an invitation to work in the call centre for the philanthropic entity. Even if among Smith's reasons to work in the call centre there is the fact that the firm has philanthropic aims, it does not make sense to say that the word "ought" be used in the sentence that expresses Smith's practical decision to work there, or that it expresses his dispositional sentiment of feeling guilty if he eventually fails to take the job. If he does so, he may feel upset in some way-he may even feel guilty — but this is not something expressed by the word "ought." My point is that Smith's sentiments are linked with the facts or reasons for accepting the job. If the facts (or reasons) were not moral, he would not feel those moral sentiments, but others. For example, suppose Smith was thinking about getting a position in a bank and eventually he reached the conclusion that he ought to accept the job. Suppose now that Smith wakes up too late and that he misses the appointment and consequently loses the job. He feels upset, but for different reasons from the previous example. Since the sentiments vary according to the reasons we have for action, these reasons are what trigger our reactive sentiments, not the word "ought." It is possible that "ought" only signalizes (linguistically, at least) those reasons with some special practical force. I think that it is very plausible that the word "ought," in sentences describing decisions, expresses that the action has some stringency. If I am right, the word stresses (or expresses) the intensity of those prescriptive sentiments (or our prescriptive dispositions) Prinz is talking about, but not those sentiments as such. The prescriptive sentiment is, hence, connected with the facts that count as reasons for acting. If those reasons are moral, the prescriptive sentiment is moral; but the reasons can be purely instrumental, and in this case the word "ought" clearly does not express any prescriptive moral sentiment. Nevertheless, the idea that we have prescriptive sentiments is a good idea, to which I subscribe.

\section{Deriving "ought" from "is."}

My queries are stronger in the case of Prinz's argument for deriving an "ought" from an "is." Let us see the argument: 
1. Smith has an obligation to give to charity if "Smith ought to give to charity" is true.

2. "Smith ought to give to charity" is true if the word "ought" expresses a concept that applies to Smith's relationship to giving to charity.

3. The word "ought" expresses a prescriptive sentiment.

4. Smith has a prescriptive sentiment towards giving to charity.

5. Thus, the sentence "Smith ought to give to charity" is true.

6. Thus, Smith has an obligation to give to charity.

Below we have the same argument with modifications for the sake of logical clarity:

1. If the sentence "Smith ought to give to charity" is true, then Smith has an obligation to give to charity.

2. If the word "ought" expresses a concept that applies to Smith's relationship to giving to charity, then the sentence "Smith ought to give to charity" is true.

3. The word "ought" expresses a prescriptive sentiment.

4. Smith has a prescriptive sentiment towards giving to charity.

5. The sentence "Smith ought to give to charity" is true (MP 2, (3\&4)).

6. Smith has an obligation to give to charity (MP 1,5).

The argument is valid. Taking the first three sentences as assumptions, if Smith is prone to give to charity (4), the conclusion that follows is that Smith has an obligation to give to charity. But the first premise cannot obviously be true. Hence, the argument is valid, but it is not correct. If the conclusion expresses a deontic state concerning Smith, there are obvious situations where it is true that he ought to give to charity without obligation. It is possible that Smith is not under any strict obligation of giving to charity and nevertheless that is what he ought to do. Why think that benevolence must always be a matter of duty? For some religious persons (a Muslim or a Christian), benevolence is a matter of duty. Perhaps Kantians think the same. Even Hume used the word obligation in his approach to his so-called "natural virtues." Should we follow Hume's careless use of obligation here? I don't think so, for it seems to me very plausible that no one has any strict (or perfect) obligation to abide such moral "natural requirements." Anyway, 
even if I am wrong (in asserting that it simply does not make sense to speak about the supposed general obligations of benevolence), there certainly are situations where a person is not under any obligation to certain philanthropic actions, though one can have good reason for performing them. If someone asks to donate to a philanthropic action for the benefit of the Haitians, and we decide to make the donation, we would certainly take this action with good reason, possibly the best. Hence, in this case, we did, in some sense, what we should have done. But to say that we were under an obligation, or a duty, to help the Haitians is beyond the truth.

Why does Prinz say something like (1)? Perhaps because he takes "ought" as a moral word and "obligation" as a non-deontic term, which I would agree with. "Obligation" for Prinz expresses a subjective state. The argument turns out to be more persuasive, since "obligation" means something like "subjectively stringent" or "subjectively demanding." The conditional sentence becomes something like this - If "Smith ought to give to charity" is true, then Smith is under a subjective requirement to give to charity. ${ }^{4}$ The practical conclusion reached by Smith expressed by the "ought sentence" implies that he sees himself committed to the fulfillment of the action described. Nevertheless, since the sentence "Smith ought to give to charity" can be true independently of Smith's practical reasoning, the above does not prove much. Suppose that John, thinking about Smith, concludes that "Smith ought to give to charity," and that this is true. This certainly does not imply that Smith feels himself obliged to perform the action. Therefore, it could be true that Smith ought to give to charity but he is not actually obligated in Prinz's subjective sense. If we try to fix the problem by saying that the antecedent should also be interpreted subjectively, the problem now is how can we make intelligible advice? In this framework, the act of advising becomes simply unintelligible. Advice is not simply the communication of our own subjective views on a practical matter; it is directed to another's interests, desires and wants, not our own.

One problem is that Prinz does not interpret both sentences in their proper objective sense. This explains why Prinz does not find John Searle's argument convincing. Searle said that when someone makes a promise (under Austinian felicity conditions), they place themselves under an obligation (Searle 1969). The idea is that obligations are matters of fact; actually, matters of conventional, or institutional fact, but social facts nonetheless (Searle 1996; Smith 2003). To promise is to say certain words under the proper circumstances, and this speech act 
consists of putting oneself under an obligation. Searle said more than this, but the following amendments are perhaps sufficient to clear up this idea.

When we make a promise we make a promise to someone. This other person becomes entitled to something by our speech-act of promising, that is they become entitled to the fulfillment of what was promised to them. To promise, then, is to alter the normative world in some way (Thomson 1990). Suppose that Smith promised a sum of money, as charity, to a philanthropic entity - Oxfam, for example. If the promise is taken seriously without any mistakes (Austin's felicity conditions satisfied), Smith has placed himself under the obligation of giving money to Oxfam. Smith was not previously obliged to give to charity, even to Oxfam. But if we take promises seriously, by the act of promising Smith has put himself under the obligation of giving money to Oxfam. An additional notion is that, before the act of promising, Oxfam could make no complaint against Smith or claim the money. But Smith's promise has created a different situation. If Smith does not fulfill the promise of giving money to Oxfam, and the company decides to complain, we would certainly understand their complaint against him.

Following this explanation, it is wrong to say that promising "is only to place oneself under an obligation if people ought to keep their promises" (EMC: 5); for people only ought to keep their promises just because to promise $i$ s to place oneself under an obligation. If a promise didn't mean the same as to place oneself under an obligation, it would be both true that people ought to keep their promises, and false that promises were to place oneself under an obligation. In this case, people could have other reasons to fulfill their "promises" (or pretend-promises) if promise meant something different than "to put oneself under an obligation," but they could not simply state that they had promised. In this case, it would be wrong to say that fulfilling a promise is not something owed by the promisor, to the promisee, unless the "owing" depends only on the promisor's desire to fulfill the promise. But this does not make sense; hence, "to promise is to place oneself under an obligation if people ought to keep their promises" is true because it is incorrect to say that both "to promise is to place oneself under an obligation AND people ought not prima facie to keep their promises." The best explanation is that it is part of the very definition of promising - that to place oneself under an obligation is to submit oneself to a duty, a deontic concept broadly defined as being committed to fulfilling an action (or a sort of action - or making it so that something occurs, and also that to have that duty is to have a reason 
for action; if one is under an obligation to duty, then they have a pro tanto stronger reason for doing something.

This conclusion is coherent with just the opposite of Prinz's remarks - if to promise is to place oneself under an obligation, then promisors, at least prima facie, ought to keep their promises. Again, the best explanation is that promises are conventional practices, understood as "normative regularities" (Williams 1999): following a conventional social rule, the promisor acts with words (Austin 1962); the performative speech act is a social linguistic device whereby one performs the action of putting oneself under an agent-relative obligation (Darwall 2006); that is, a duty towards another person conventionally identified as one's promisee. Of course, it is always possible to ask, considering all the circumstances, if the agent actually ought to their duty. But even if it is true that an agent ought not fulfill their promise in some especial or casuistic circumstances, the fact that they had a duty to fulfill the promise continues to be true (for this fact is a conventional consequence of the speech-action). Suppose that Smith's wife was kidnapped and he had previously promised to give money to Oxfam. Some people could think that in this case his previous duty to give money to Oxfam no longer exists. But, in this scenario, would he think (as might Oxfam) that he should apologize? If a duty no longer exists, is there any reason to apologize? If he no longer has a reason to apologize, he did not even have a duty in the first place. But if he did have a duty, the proper answer would be that, considering the newer circumstances, Smith ought not to give Oxfam his money, even if it is still true that Oxfam could have a complaint.

Consider a very different situation, but one that is simpler and clearer. This is one of Judith Jarvis Thomson's examples (with some modifications for the sake of my argument) that she presents in The Realm of Rights (1990), and the view on the matter is originally hers. Imagine that a person, Pedro, promised one apple to a friend, Maria. Following the very meaning of promising, this occurrence implies that Pedro put (or committed) himself to an obligationthe obligation of giving Maria one apple. But Pedro is, unfortunately, a forgetful person. A day later, Pedro meets Alfredo and promises him one apple too, committing himself to another obligation of giving Alfredo one apple. Nevertheless, Pedro has only one apple at home and he cannot get more fruit. He knows that he has only one apple, he knows that he cannot get more fruit, and so he is in trouble. What should he do? Well, he simply cannot fulfill both promises. Someone could think that, since "ought implies can," this implies that he ought not fulfill at least 
one of his promises. In one sense, this is true. He simply cannot fulfill both promises; in practical terms, to fulfill both promises is something outside the scope of his choice. Nevertheless, in another sense of "ought," Pedro still "ought" to fulfill both promises. This explains why people think that he ought to at least apologize, or to compensate. Suppose that Pedro concludes that he should fulfill his promise to Maria, but compensate Alfredo. Maria is his girlfriend, and she does not have a good temper. Alfredo is a friend, and fortunately for Pedro he likes oranges, and Pedro has an orange at home. He decides to give an orange to Alfredo, and apologizes. He thinks that Alfredo will understand, and he is quite right about this. He explains the situation to Alfredo, who understands and says: "No problem." Pedro's decision was practical; he realized that what he should do was fulfill his promise to Maria and give Alfredo an orange and apologize. This was a good decision; nevertheless, Pedro certainly owed to Alfredo not an orange, but an apple. The first "ought" is therefore very different from the last. The first "ought" was about what Pedro owed to someone else; the second was about the best possible decision considering the circumstances. The two are interrelated, for the second is a reason for the first, but they are not semantically the same.

\section{On "ought" and "duty"}

"Ought," let us admit, is also a weasel word. "Ought" can mean different things, and it can also simply mean nothing (as a matter of fact, it can be used - mainly in Philosophy - in nonsensical ways). The same applies to "right" and "wrong" or "good" and "bad" (we have a pack of those weasels in Philosophy). Several philosophers have tried to analyze those terms, but my preference is with Peter Geach (2002, 64-73) and Judith Jarvis Thomson's clarifications (1990). Let me now simplify Thomson's view.

Thomson's writings on "good" and "goodness" are analytically marvellous. Simplifying a bit, her view is that there is not good or goodness as such; there is only good and goodness "in a way." But since I don't have space and time to deal with this topic here, I'm going to weasel out of it — sorry. I'll just stick to the analysis of duty and ought.

Thomson's concept of duty comes from the jurist Wesley Newcomb Hohfeld (1913, $1917,1919,2000)$. Following Hohfeld, to say that a person has a duty to do something, say $\varphi$, is equivalent to saying that they do not have the privilege of not $\varphi$ ing. Hohfeld talked about legal 
concepts, but we can apply the same idea to the alleged moral concepts of "moral duty" and "moral privilege."

Hohfeld-Thomsonian duty is a two-hat-concept, says Thomson. To have a duty is to have a duty concerning someone; hence, all duty-bearers are always correlative right-holders. Rights are the correlatives to duty (Feinberg 1970a, 1970b). I do not believe that we could have any other kind of duty, except the Hohfeldian kind. ${ }^{5}$ Even duties to obey imply a right of being obeyed, and I don't think that commands, even valid commands, imply duty (like the Hobbesians think, for example). To obey is a matter of compliance to a command. I can obey invalid commands (for a lot of reasons, both prudential or instrumental). Obeying valid commands, nevertheless, is a normative matter.

Ought is not, however, a two-hat-concept. It is a one-hat-concept, applying only to the agent. It is a word that expresses, for example, the better decision between alternatives. If I'm thinking about what is the best route to go from my home to the University Campus, I'm thinking about what I ought to do concerning this matter; that is, the matter of going from my home city to the University. This word, as such, does not have any special moral meaning. Hence, our duties concern morality, but not necessarily our "oughts."

And what about "obligations?" Obligation, of course, is also a weasel term. It can mean the same as duty, but it can mean something different (besides nothing). It can mean, for example, something we have to do (or ought to do) because, at least for one reason, we have a duty. I will use "obligation" here in this sense.

I propose to distinguish "obligations" (in whatever sense) and the "sense of obligation," and the so-called "sense of duty." I confess that I'm not sure if it makes sense to distinguish the "sense of obligation" from the philosophically more traditional "sense of duty." But consider this possibility - a sense of duty is the sentiment we have when we know (and necessarily feel) that we are duty-bound. In turn, the sense of obligation is the sentiment we have in a concrete situation when we conclude in favour of doing something because (besides other reasons) we have a duty to it. A sense of duty is, in consequence, a sentiment we feel in the mere act of thinking about our duties, even hypothetically; but a duty becomes an obligation only in practical situations (this is perhaps the emotional side of the thought that duty binds agents, both prima facie and actually). The sense of obligation is the sense attached to the conclusion that what we must do is what we are duty bound to do. Nonetheless, there are exceptional situations where we 
definitely have to do something contrary to our duty. There are several situations where it is possible to have doubts and we have to decide, without full conviction, that we reasoned correctly. Actually, it is also possible that we have the conviction that we reasoned correctly, and yet still feel uneasy concerning the decision. A sense of obligation can diminish in force if the practical situation is one where we have reasons, perhaps strong reasons, for acting contrary to our duties. There can also be situations where the sense of obligation simply vanishes, given the likely obsolescence of duty. If those situations were common, and generalized, we set for a radical normative change.

Prinz said that "ought" expresses a "prescriptive sentiment." One type of prescriptive sentiment is the sense of obligation. This "sense of obligation" is connected to "ought." I suppose that this is what Prinz envisaged by his principle that "ought" implies "a prescriptive sentiment." Hence, if someone concludes that they "ought to $\square$," they are expressing a prescriptive sentiment. I prefer to say that when someone concludes that they ought to $\square$, if they also have a duty to $\square$, they simultaneously feel a "sense of obligation"- a prescriptive sentiment possibly towards themselves.

But they could be wrong. It may be a falsehood that that ought to $\square$. The sense of obligation is attached to concluding that they ought to $\square$, but they can still feel a sense of obligation even if it is true that they ought not to $\square$. A possible reason for this conclusion is, for example, that they did not reason well. In this case, an ulterior reflection could make them feel embarrassed, ashamed or even guilty for their bad decision.

Prinz accepts the difference between the sentence "They ought to $\square$ " and the fact that they ought to $\square$, saying that it is possible that the first is true, and the second false. But consider Prinz's example of Smith's obligation to give to charity. Since for Prinz the sentence "Smith ought to give to charity" is true if the word "ought" expresses a concept that applies subjectively to Smith's relationship to giving to charity, the only conclusion Prinz can possibly arrive at, following this assumption, is that the agent has an actual sentiment of obligation, but not an actual obligation to give to charity. That is, "Smith ought to give to charity" is nothing more than the fact that Smith has a feeling of obligation to give to charity. The fact that someone ought to $\square$ - and this is my interpretation of Prinz' view—is only a sentiment concerning the agent. This sentence can of course be true, for it is the conclusion of an agent's practical reasoning. But it is also compatible with Smith being wrong. However, in Prinz's view, Smith simply cannot be 
wrong. This is plain subjectivism-I cannot see how plain subjectivism can be compatible with normative realism.

This becomes clear if we take the first of Prinz's premises: "If 'Smith ought to give to charity' is true, then Smith has an obligation to give to charity." For a normative realist this premise is false. The case for there being an obligation is rooted in social facts and deeds. Reasons for action are what make the case that one ought to do something. This last statement can be considered true, and if so the prior statement as a consequent is false. It is possible that one ought to give to charity even if there is not any obligation grounded in the social facts of giving to charity. However, "Smith ought to give to charity" cannot be proved true simply because it expresses a prescriptive sentiment, for it can express the sentiment and be normatively false. Hence, ought can express a concept that says something about Smith's relationship to charity, even if Smith actually ought not to give to charity. Prinz excludes this last possibility by definition. I include it empirically. The reason is that both sentences are empirically independent. The set of facts that ground the first is not equivalent to the set of facts that ground the second. The first idea expresses something about Smith's mental state; the second expresses a bit more, including social normative facts, which are occasionally in conflict with Smith's mental state.

I agree that to acknowledge a duty implies an appropriated prescriptive sentiment, and an appropriative reactive attitude. What explains this is the fact that to acknowledge (internally) a duty is to "follow a rule." It is to develop a moral habit, and this involves an attitude. But the duty can exist without the prescriptive sentiment; it is possible that an agent eventually does not acknowledge their duty or it is possible that they acknowledge their duty only in an "external" sense (they could be psychopathic). It is also possible that the prescriptive sentiment becomes weak within the mind in the long run (see Nero's example in Hume). This does not imply that duty and sentiment are completely unrelated. They can be naturally related (and, in some sense, epistemically).

One possibility is that custom produces sentiment. This, I think, is Hume's alternative for the apparent mysterious link between norms and self-motivation. The idea is that the habit of following a conventional rule - in Herbert Hart's $(1961,56)$ sense of the "internal aspect" of rule following - is naturally attached to a sentiment (this is also naturally linked in the sense that it is "cerebrally" linked). When someone learns how to follow a conventional rule, they also naturally develop into their mind a sentiment; otherwise they probably would not learn the rule correctly.

ethic@- Florianópolis v.12,n.2, p.143 - 168, Dez. 2013. 
Therefore, a habit creates an appropriated sentiment. The habit of following deontic (conventional) rules in the internal sense is connected with a deontic sentiment- - this is the sense of duty.

My preferential view on this issue is that the sense of duty emerges from the recognition of other's claims. How do we learn to recognize claims? We learn it by putting ourselves into other's shoes and developing empathy; that is, when we learn to adopt second-personal standpoints (Darwall 2006). Assuming a second-personal attitude implies recognition of other's demands; especially claims. To grasp another's claim is eo ipso to grasp a duty, and to grasp a duty is to grasp a particular, or an agent-relative reason for action. The basic premise is-if another has a valid claim against me, $I$ am submitted to the duty of respecting it. I cannot understand the other's claim against me as a claim without understanding eo ipso that I am under a duty concerning them. Duties are strong reasons for action. Duties are also connected to potential enforcement in the case of infringement of duty. This is why when one realizes that one is under duty it registers on a practical and personal level.

The rule is - if I have a duty, then I have a strong prima facie reason for action. It functions like this - first, agents internalize the rule (this is what we mean by a "habit"); but it is only through reflection that they could grasp its proper nature (and then only perhaps under sophisticated reflection). To internalize the rule is to recognize that duties are strong reasons for action in a practical sense (that is, it is to form an attitude, or a pro-attitude, concerning the idea that claim imply duty — an oughttitude in Prinz's ingenious words). In effect, when we learn the meaning of a claim, we also learn that claims strongly demand actions; an idea that is expressed when we say that others' claims authorize actions as practical conclusions (at least, prima facie) when we think about what we ought to do in circumstances where respect for claims are involved.

\section{On relativism}

Compare Prinz's view on the problem of relativism and our attitude towards Akamaran cannibalism. Prinz contrasted two views on the normative: absoluteness and relativism on norms. Let us assume that absoluteness is false. Assuming that moral absolutism is false does not skew us towards agent-relativism - there are other possibilities. Contextual normativism is one 
possibility, and this includes traditions, roles, group-practices and law—Prinz actually conflates both views. In this case, a norm is binding for agents only within a contextual practice. These norms are not binding because agents take them as such; their bindingness does not depend on the values an agent happens to endorse, because they depend on values intrinsically associated to social practices - an agent's opinions on those values are another matter. Ought-sentences, in this case, convey those personal moral opinions, but they are used in bad-faith if they are invested with the categorical sense of duty.

Let us look at two different kinds of example. The first is on the so-called notion that "it is wrong to lie." Additionally, we will observe that "it is wrong to not maximize utility." In both cases, there is a rule, a moral (or eventually a legal) rule, but also a social fact- the social fact that some people have a duty to behave in a determinate way concerning other people's claims, or the social fact that some directives should be followed by people in determinate roles. Lies are wrong only in a context where someone imposes a claim against us not to lie (remember Benjamin Constant's criticism against Kant on the supposed impermissibility of lying). It is wrong not to maximize utility only for people with the duty to maximizing utility. In other cases, maximizing utility is perhaps advisable, but not obligatory.

Social facts and normativity, therefore, are intimately connected. A general rule applies to persons within their roles. Only moralists and philosophers try to think (in error) beyond those contexts. Consequently, a false theory develops and explains why Mackie was right about some views on morality.

Let me state another point on which Prinz and I differ. I don't think the locus for understanding our diversity of values is culture, but rather practice. Culture is a broad term for a stable group of more or less fixed or institutionalized traditional social activities and practices. Practices live together, in a time and place, within one "culture" in a more or less "homeostatic stability" (Boyd 1988, 197). Perhaps a culture is (besides other things) a stable cluster of social practices. For example, religion is a social practice, but one that varies within different cultures. A culture is a local and historical presentation of integrated clusters of social practice. In this sense, culture is broader and involves a set of practices. In another sense, culture is used to refer to common beliefs within a defined group; for example, scientific culture and scientific practices, religious culture and religious practices, an economic culture and economic practices, etc. My point concerning this second view on culture is that cultures are epiphenomenal; what makes and 
sets some particular culture is the contingent dynamic equilibrium of social practices. Social practices are perhaps the "genes" of cultural evolution. If each culture is like a specific DNA, a big cluster of practices are the genes.

All rights and wrongs depend on contextual practices; a practice is a ruled behaviour. A broad and influent definition of practice is the definition presented by MacIntyre: "Any coherent and complex form of socially established cooperative human activity through which goods internal to that form of activity are realized in the course of trying to achieve those standards of excellence which are appropriate to, and partially definitive of, that form of activity, with the result that human powers to achieve excellence, and human conceptions of the ends and goods involved, are systematically extended." "A practice," says MacIntyre, "is any coherent and complex form of socially established cooperative human activity. [T] he range of practices is wide: arts, sciences, games, politics in the Aristotelian sense, the making and sustaining of family life, all fall under the concept" $(2007,187)$.

MacIntyre's is a fine definition of practices; but it does have some problems. His view on practices as contrasted with institutions is good but problematic; both are, in his view, situated in opposite and conflicting sides (similarly is Hayek's account of contrast between spontaneous orders and "organizations"). But the fact is that social practices - at least some of them-only exist because there are institutions that control and support them. Some are genealogically independent from their actual institutions, like games and scientific practices, for example. Others were likely raised within institutions, or evolved therein. Games, for example, are independent from sports institutions; but modern sport evolved to become a different practice than mere games within sportive institutions. Hence, a different practice evolved, guided by the institution. It is very plausible that the practice of magistracy (the Holmesian profession) is essentially connected to the institution of the magistrate, as is the practice of justice, and its judiciary institutions (also called "Justice"). Those practices probably evolved from previous, older forms, and the changing institutions possibly shelter different, but related, practices with a conflictive coexistence.

I suspect that MacIntyre's definition is biased by his own adherence to his substantial views on normativity and law; hence, his view is biased by his own opinions on the matter of ethics. This I suppose can explain why he is skeptical about the possibility of seeing business, for example, as a practice (Moore 2002). 
As previously stated, "ought" is a word that marks the stringency of reason. Moral reasons (duties, for example) are paradigmatic examples of strong reasons for action. Nevertheless, that "duty implies ought" cannot be interpreted literally as a conditional, for imply means just that — an implicature.

We can understand the rule that "duties imply oughts" as a material rule of inference (Sellars 1953, Brandom 1994). This presupposes a non-formalist conception of reasoning and practical reasonableness. The basic idea is that certain concepts (like concepts materially connected to institutional facts) involve practical commitments. Take MacIntyre's example of a sea-captain. There is surely an "ought" that we can derive from an "is"- that the Sea-Captain ought to fulfill their duties if they actually are a sea-captain. The same applies (and is more transparent still) with "good." We can certainly infer from facts that someone is good or not. MacIntyre's example is this: "He gets a better yield for this crop per acre than any farmer from his District." This is good evidence for the statement, "He is a good farmer" $(2007,58)$. This is true because "farmer" is a functional concept (see Thomson about "goodness"). We cannot conceive of goodness without thinking about a functional skill or role.

My suggestion is similar, but has more steps. First, there are the descriptive derivations from the fact that sea-captains have specific obligations (duties), and from these we can infer a practical rule - that sea-captain have pro-tanto reasons for actions of fulfilling their duties as seacaptains. This is what we mean by assertions like "sea-captains ought do this or that." But the question "Considering all circumstances, what ought John, the sea-captain, do?" cannot be answered outside a concrete practical situation. Nevertheless, sea-captains ought to fulfill their duties as sea-captains. All duties apply to persons in certain roles or situations. Even if we consider cases where persons are viewed as "persons as such" (or "human beings"), on closer inspection we will note that we are thinking about some kind of role-duty, like duties as citizens, duties as parents, duties as friends etc. We can thing that we ought to accomplish certain things without thinking about special duties when we are thinking about our special personal interests. But I'm not sure that if, in those cases, we are simply borrowing the psychological force of "duty" to strengthen our practical conclusion that concerning that which we care about, or about what we perhaps correctly conclude, instrumentally serves our best personal interests. Nevertheless, it is difficult to think of situations where no duties are involved at all. 
Does my view imply relativism? I don't think so, but perhaps it is compatible with a softer version or moral relativism. Anyway, Prinz remarks that there are two different kinds of "relativisms": truth-relativism and subjective-relativism. The prevalent idea within relativist philosophers is that with subjective-relativism right and wrong are relative to the subject's own views on the matter. Following this last trend, moral thinking and action are plainly subjective. Therefore, there is a tendency to conflate fully-fledged subjectivism with relativism. There are other kinds of "relativism," perhaps softer than those fully-fledged views.

What kind of truth-relativism is non-relativistically true? That belief is only true contextually, or not, depends on empirical facts. That morality is contextually true is a matter of fact. If by morality we mean the same as John Austin, the great philosopher of law of the nineteenth century (a view on morality that I suggest we should hold), it is contextually true that different "moralities" can diachronically, or even synchronically, exist. Nevertheless, if by "morality" we mean the same as Kant, it is conceptuality impossible (perhaps by definition), for it is simply analytically false that morality is context dependent. The problem is that there is no contextually-independent empirical morality; this phenomenon simply cannot not exist. Kant and the Kantians nevertheless would agree with this, since for them morality is not phenomenic. I will not argue here in defence of Austin's view; nevertheless, it seems very plausible in a naturalist guise that there cannot be a non-phenomenic nor a noumenal "morality" (other things can be true apriori, but not morality). Therefore, only "Austinian moralities" exist.

Communities and groups moralize (in this Prinz is right), but they moralize spontaneously, without the intention to moralize. Persons moralize too, but they usually do this intentionally. Both processes can coexist and, possibly, the latter is part of the former. Accepting this dialectic is problematic for Prinz's individualistic relativism. It is problematic because what is at stake is the supposed autonomy of the individuals of a community adhering, or not, to the normativity of the communities' social practices that they are personally involved in.

A social view on morality does not imply subjective-relativism, or Prinz's speakerrelativism (or even his intersubjetive relativism, for it is grounded in the agent's free decision, and this is not empirically true). It is a contingent and historical fact that we live under general rules that we cannot but live without contextually. Normativity is empirical, and being empirical it is a matter of fact. Could it be any different? What I'm suggesting is that normativity as such (the norms by which people actually live and behave) is a social phenomenon that we, as persons 
or agents, cannot be rid of (except in an abstract fashion, as in philosophy_-but we should pay attention to what social experiments in moral psychology show about how people like philosophers actually behave in experimental, as well as in real, situations. Our moral theories should be capable of explaining that, unless they are only fantasy or poetry).

There is a place, then, for a sort of "constructive sentimentalism" in Prinz's sense (and a kind of meta-ethical relativism). It is compatible with a kind of contextually dependent truthrelativism that does not imply that the same moral statement can be both true and false. Here, I will consider only deontological statements (I will not consider non-deontological statements, that is, evaluative statements, or statements about the supposed "goodness" of something-there are reasonable views that statements such as those should be interpreted objectively. See, for example, Boyd's approach on goodness as a homeostatic cluster property, and Thomson's nonconsequentialist alternative interpretations. On Boyd's view, see Prinz's comments in his book). Let us take descriptive relativism. Statements like "killing is wrong" serve as a paradigm example of a moral sentence that can be both true and false. But it seems absurd for philosophers to assert both the affirmation and the negation of this sentence just because they think that those general moral statements are, as literally interpreted, normatively meaningful. They think this way because they see that moral judgments are literal expressions of moral laws; general judgments that express laws in analogy to physical laws. "Water freezes at $0^{0} \mathrm{C}$ " is a general law. This means that, in normal physical conditions, any amount of pure water freezes at $0^{\circ} \mathrm{C}$. If you find a liquid that does not freeze at this temperature either this is not pure water or the physical conditions are not normal (as stipulated). Some philosophers think that this idea also applies to statements like "killing is wrong". You would not be right if you thought that killing is acceptable, except in conditions very different from the regular or the "normal." For example, killing in self-defence is not wrong, but the conditions are not normal. Note that this is actually very misleading, for in fact there is no meaningful general statement that says killing is wrong as such. Killing is deontologically wrong only in two different senses. If we interpret "killing is wrong" as an expression of a command then it is not a sentence that can be true of false, for commands, imperatives and the like are not sentences that can be true or false. If moral sentences were imperatives, non-cognitivism would be true. Nevertheless, we can use sentences like "killing is wrong" in the assertion-mode (the Frege-Geach problem). For quasi-realists (Blackburn 1993), those sentences, interpreted literally as assertions, need an appropriate 
semantic interpretation to be capable of being either true or false. What a realist needs are not descriptions like "there is a law $x$ in a legal or a quasi-legal system that displays that 'Killing is wrong"” (being the enclosed sentence interpreted as an imperative, like "Do not kill!"); what they need is a truly normative-sentence expressed in the assertoric mode. Legal (and moral) statements about rights and duties can be presented as good candidates. Those sentences would say something like " $X$ has a legitimate (legal or moral) claim-right against $Y$ that, ' $Y$ does not kill $X$ "' (and the sentence enclosed now is not a command, since it expresses a state-of-affairs). The sentence can be true or false. This sentence can be both true and false if its range (or the scope of the modal operator) applies to all persons or individuals in all times and places, in an "agentneutral" mode (Nagel 1970), but it cannot be true or false if this scope is limited. My conclusion is simply this - this sentence (as a normative assertion) is nonsensical if applied to an unlimited scope. It only has meaning when applied to a limited scope (where it is possible to interpret them categorically). In those applications they are not sentences that can be both true and false. Prinz, I think, would agree with this; moreover, he prefers to say that "contexts are determined by speakers' values" (see ECM, 195), but I think that just the opposite is true-speaker's values are determined by social and historical contexts. If a sentence is relativistic, and its meaning varies depending on the speaker's idiosyncrasies, then those above sentences are not examples of relativistic sentences for their interpretation is always categorical.

I can accept that some kind of normative-relativism is true, such as the view that agents cannot simply rid themselves of the norms they are subjected to without some normative, and emotional, consequences, unless they are pathologically "emotionally blinded" (see Prinz's comment on Blair's view on EMC pages 43-5), even if they have beliefs contrary to the prevalent norms (and if their opposing beliefs are reasonable). This is an emotional consequence of the categorical sense of deontological norms (the norms that underlie categorical sentences of claims and duties), and this also supports what Prinz called motivational internalism (EMC, 1819). Nevertheless, the fact that people express emotional reactions (even mildly) when they depart from conventional rules they don't like or disagree with, does not imply absoluteness (Thomson 1990). A categorical duty does not imply a categorical ought. Actually, there are no categorical oughts. A duty is a strong reason for action, but it is not absolute. There are situations where an agent can have good reason to act contrary to what their duty requires. This is compatible with the fact that normal people display emotional reactions when they depart even 
from the norms to which they disagree. The absence of categorical oughts is compatible with the view that duties, as such, are categorical; moreover, the non-absoluteness of oughts, and the categorical character of duties, actually helps to explain the conflictive emotional experiences of normal people (that is, people without moral blindness). Would it mean that "ought" sentences are relativistic? I do not think so.

People are usually required to obey commands and respect rights, but it is a fact that people disobey commands as well as their categorical duties. Disobedience is manifest in actions. Actions can be done with or without good reasons. There are certainly situations where people have good reasons to disobey commands or disrespect duties. This social phenomenon helps to explain the internal tension within the reasons for sustaining a practice of following norms, and the emergent reasons for changing them. It is possible to imagine a situation where we have good and stringent reasons to disobey or disrespect a duty. If those situations are common, regular or persistent, we do not only have reason to depart from the norm but to change them. Our personal beliefs and reasons for action are a matter of politics; norms are a matter of deontology. There is place for relativism, for people agree that occasionally a meaningful norm should be removed or transformed by political action. My conclusion here is that norms are not timeless. They apply to determinate people, places and times, but they do not vary depending on subjective personal beliefs and their subjective variable passions.

Let me now evaluate some of Prinz's ideas concerning relativism. Consider Prinz's belief that, "if agent-relativism is false and constructive sentimentalism is true, then when a member of another culture judges that we ought to refrain from doing something, we would be under an obligation to refrain." If we see things my way, this conditional is simply false. The antecedent can be true, and the consequent false. It is possible that agent-relativism is false, and constructive sentimentalism is true (understood as the view that a common-normative behaviour can evolve constructively, and politically, by interactions of different normative beliefs), and when a member of another culture judges that we ought to refrain from doing something, we still would not be under obligation to refrain. Why? Because the obligation to refrain is not a matter of our opinion or personal judgment. It is a matter of what we actually are and how we behave. Both ideas are false: if someone from another culture judges that we ought to refrain, we ought to refrain; and if a person of another culture judges that we ought to refrain, we have an obligation to refrain. But of these, the second is worst. The first occasionally (contingently) is true; the 
second never. Because the second is blocked by a semantic thesis about duties and obligation, we cannot have an obligation simply because another thinks that we do. Obligations are matters of fact (that is, normative social facts); they are matter of real social practices. ${ }^{6}$ If they weren't, or rules would be unattainable transcendental entities, or they would be private things (or simply imaginary rules, perhaps). In the first case, rules would be completely outside the natural realm (and it would be completely unexplainable how they could influence human behaviour). In the second case, to think that we are following a rule would simply mean that we are actually following the rule; but this, as Wittgenstein showed us, cannot be true. My Thomsonian proposal of distinguishing "duties" from "oughts" has the advantage of not falling into those two errors, but especially the second. Prinz's agent-relativism is unfortunately subject to this second type of error and that is my main complaint against it. 


\section{Notes:}

${ }^{1}$ Professor of Philosophy at the University of the Sinos Valley (UNISINOS), São Leopoldo, Rio Grande do Sul, Brazil.

${ }^{2}$ What Hume said in the widely quoted passage of his Treatise (in the last paragraph of the first section of the first Chapter of Book three) was that the "vulgar systems of morality" were incapable to explain how is it possible to pass from an "is" to an "ought," an inference "altogether unconceivable" following the assumptions of those theories based in metaphysical (unproved) statements derived from the traditional or modern natural law theories, or simple theological views.

${ }^{3}$ Stanley Cavell once remarked that 'ought' is a mode of presentation of the conclusion of a practical reasoning (Cavell 1979, 323).

${ }^{4}$ But what should we mean by a "subjective requirement?" Would it be a kind of agent-relative moral requirement, or constraint to the action? If this is the idea, then it would be indistinguishable from the deontic moral notion of duty (for duties are strict agent-relative moral requirements, as I think, by definition).

${ }^{5}$ There are disagreements. Joseph Raz $(1988,170)$ and John Finnis $(2011,199-226)$ think that the Hohfeldian schemes do not fit all forms of rights, in the moral and legal domain. I disagree (see OLIVEIRA, 2010).

${ }^{6}$ We can take the idea of a normative practice as similar to what David Copp call a "standard" (Copp 1990, 2001); but, in this case, it is necessary to present the following caveat. Copp claims that moral codes (or standards) are not as such true of false, so they are not things that can be empirically confirmed. What can be confirmed are propositions about them. So it is not true that the bishop only moves diagonally. What is true is that it is a rule of chess that bishops only moves diagonally. Hence, what is true here is the proposition not the rule itself. If we apply this lesson to my assertion above about "obligations", it could be thought that it is wrong to say that "obligations are matters of fact, that is, normative facts". Nevertheless, my approach is consistent with the distinction between the standard (the code, the rule, the practice) and the propositions about it. So, if I interpret correctly a standard (of course, a standard appropriately applied to me), I can correctly draw practical conclusions about what I ought to do. My point hence is that obligations are matters of normative facts relatively to some standard (or a code, or a system of norms). It is a different "normative" issue if we have to follow some standard in some specified and contextualized situations, that is: statements of duties are not equivalent to (practical) judgements about what we have to do (signalized by the term 'ought').

ethic@-Florianópolis v.12, n.2, p.143-168, Dez. 2013. 


\section{References:}

Azevedo, Marco Antonio. 2010. "Rights as Entitlements and Rights as Claims". Veritas 55 (1): 164-182.

Austin, John Langshaw. 1962. How to do Things with Words. Oxford: Oxford Clarendon Press.

Blackburn, Simon. 1993. Essays on Quasi-Realism. Oxford: Oxford University Press.

Boyd, Richard. 1988. How to be a Moral Realist. In Sayre-McCord, Geoffrey (Ed.), Essays on Moral Realism. Ithaca/London: Cornell University Press.

Brandom, Robert B. 1994. Making it Explicit. Harvard University Press.

Cavell, Stanley. 1979. The Claim of Reason. Oxford: Oxford University Press.

Churchland, Patricia. 2009. "Inference to the Best Decision." In Bickle, John (Ed.), The Oxford Handbook of Philosophy and Neuroscience. Oxford: Oxford University Press.

Copp, David. 1990. "Explanation and justification in ethics." Ethics 100 (2): 237-258. 2001. Morality, Normativity, and Society. Oxford: Oxford University Press.

Darwall, Stephen. 1996. The Second-Person Standpoint. Harvard University Press.

Edmundson, William. 2006. “The Virtue of Law-abidance." Philosopher's Imprint 6 (4). Acessed October 12 (2013), at http://hdl.handle.net/2027/spo.3521354.0006.004.

Feinberg, Joel. 1970a. "The Nature and Value of Rights." Journal of Value Inquiry 4: 243257.

—. Doing and Deserving. 1970b. Essays in the theory of responsibility. Princeton: Princeton University Press.

Finnis, John. 2011. Natural Law and Natural Rights. 2nd Edition. Clarendon Law Series. Oxford: Oxford University Press.

Geach, Peter. 1976. "Good and Evil." In Food, Philippa (Ed.), Theories of Ethics. Oxford Readings in Philosophy. Oxford: Oxford University Press.

Hare, Richard M. 1963. Freedom and Reason. Oxford: Oxford University Press.

Harman, Gilbert. 1986. Change in View. Cambridge: MIT Press. 
1976. "Practical Reasoning." Review of Metaphysics 29: 431-463.

Hart, H. L. A. 1961.The Concept of Law. Oxford: Oxford University Press.

Hohfeld, Wesley Newcomb. 1913. "Some Fundamental Legal Conceptions as Applied in Judicial Reasoning.” The Yale Law Journal 23: 16-end.

—. 1917. "Fundamental Legal Conceptions as Applied in Judicial Reasoning." The Yale Law Journal 26: 710-end.

—. 1919. Fundamental Legal Conceptions as Applied in Judicial Reasoning (and other legal essays), Ed. Walter Wheeler Cook. New Haven: Yale University Press, Republished 2000.

MacIntyre, Alasdair. 2007. After Virtue. Third Edition. Notre Dame, Indiana: University of Notre Dame Press.

Moore, Geoff. 2002. "On the implications of the practice-institution distinction: MacIntyre and the application of modern virtue ethics to business." Business Ethics Quarterly 12 (1): 19-32.

Nagel, Thomas. 1970.The Possibility of Altruism. Princeton: Princeton University Press.

Prinz, Jesse. 2007. The Emotional Construction of Morals. Oxford: Oxford University Press.

Raz, Joseph. 1988. The Morality of Freedom. Clarendon Press.

Searle, John. 1969. Speech Acts: An Essay in the Philosophy of Language. Cambridge University Press.

—. 1996. The Construction of Social Reality. Penguin Books.

Sellars, Wilfrid. 1953. "Inference and Meaning." Mind, New Series 62, 247: 313-338.

Smith, Barry. 2003. "John Searle: From Speech Acts to Social Reality." In Smith, Barry (Ed.), John Searle: Contemporary Philosophy in Focus. Cambridge University Press.

Thomson, Judith Jarvis. 1990. The Realm of Rights. Harvard University Press.

Timmons, Mark. 2013. Moral Theory: An Introduction. Second Edition. Lanhan/Mariland: Rowman \& Littlefied Publishers.

Williams, Meredith. 2002.Wittgenstein, Mind and Meaning: Towards a Social Conception of Mind. London: Routledge. 